\title{
Politics with Hidden Bases: Unearthing the Deep Roots of Party Systems
}

\author{
Kevin P. Byrne and Eoin O'Malley
}

The research presented here uses a novel method to show that contemporary party systems may originate much further back than is usually assumed or might be expected-in reality many centuries. Using data on Ireland, a country with a political system that poses significant challenges to the universality of many political science theories, by identifying the ancestry of current party elites we find ethnic bases for the Irish party system arising from population movements that took place from the 12th century. Extensive Irish genealogical knowledge allows us to use surnames as a proxy for ethnic origin. Recent genetic analyses of Irish surnames corroborate Irish genealogical information. The results are particularly compelling given that Ireland is an extremely homogeneous society and therefore provides a tough case for our approach.

Keywords: party system formation; cleavages; ethnicity; Ireland

\section{Introduction}

Party systems are usually thought to be the political manifestation of the social structure in a country, which taken with values and political organisation form cleavages. These cleavages, Seymour Martin Lipset and Stein Rokkan (1967) suggested, were based on revolutions: national, cultural, religious and industrial. For them the salient revolutions were ones that took place after the 17th century. These revolutions shifted resources and preferences, and caused new groups to be formed. The interaction of these groups and particularly their elites led to the formation of coalitions of interests and, in conjunction with institutional constraints, to the formation of party systems. As such the democratisation of much of Europe in the 20th century saw the emergence of new institutional architecture and the ceding of political power to groups hitherto without formal access to power structures, which in turn saw the emergence of modern party systems.

But the Lipset and Rokkan model, although powerful, has worked less well since the late 20th century, and was never very useful in some places such as Latin America. Even within Western Europe, Ireland has a remarkably homogeneous population and is dominated by two conservative parties, Fianna Fáil and Fine Gael, whose programmatic differences are neither great nor clear. There are no clear social bases or strong differences in values to explain the country's remarkably durable organisational political divisions. In sum the bases for the Irish party system appear not to exist if we take any interpretation of cleavages the literature suggests. 
In this article we hypothesise that the basis for Ireland's unusual party system is rooted in migrations that took place from the 12th century. While the descendants of these peoples no longer form distinct ethnic or social groups, or are cognisant of shared ethnic origins, ${ }^{1}$ they may form the bases for different political traditions and sets of values. Recent genetic analyses of Irish people and their surnames corroborate Irish genealogical information. The extensive Irish genealogical knowledge allows us to use surnames as a proxy for ethnic/migratory heritage. Linking the surnames of Irish political elites with their latent 'ethnic' heritage, we test to see if there are underlying biases in the parties' representatives' surnames which would provide empirical support for our hypothesis. We find that the representatives from Fianna Fáil and Fine Gael have significantly different distributions in surnames.

This study has four conclusions that are of interest to the broader comparative literature on social cleavages and party formation. These are:

(1) The revolutions that cause the formation of cleavages can be much older than is usually assumed or might be expected.

(2) The social structure that is the basis for party system formation may be hidden, and remain hidden for many centuries, yet still be potent because of its impact on people's values.

(3) Ancient and submerged social divisions can re-emerge during transitions and depend on political agency to mobilise groups with different values.

(4) Ethnic heritage can have an impact without the descendants of members of those groups being conscious of the group having existed or their ancestors' membership of it.

In this article we briefly look at the literature on the emergence of party system and then that on the Irish party system. We set out the theory in more detail, outlining the causal mechanism. We spend some time making the argument about specific historical bases of the Irish party system, before testing the hypothesis using surname data.

\section{The Determinants of Party Systems}

We can see that political systems are rooted in historical events (Tilly 2006), but it is not often known or investigated how far back in history one can profitably study. Modern events such as the reduced number of manual working class, or the movement of large sections of the population to suburbs, have affected party systems, causing parties to realign. But the realignments have not been as extensive as one might expect. This may be because group attachments are more stable than once thought and can be based on events deeply rooted in a country's history.

The nature of cleavages and how they are formed and translate into party systems is not always clearly exposed. Mariano Torcal and Scott Mainwaring (2003) see three interpretations of the nature of cleavages and party systems. These can be thought of in terms of the degree to which structure or agency are important in the formation of a party system. The first sees cleavages as the result of objective social relations where members of groups share interests, which are reflected in their political activity. So as Anthony Heath argues, cleavage divisions can reflect divi- 
sions between 'real groups with distinct political interests' (Heath 1981, 51). These divisions which are 'real' then determine the party systems. A middle course between cleavage structure and political agency is taken by Stefano Bartolini and Peter Mair (1990, 215) and Hans-Peter Kriesi (1998) where these groups exist in the sense that there are groups with a structural social base who share certain normative political values that can be given articulation through political organisation. All three of these elements are then necessary for it to be regarded as a 'full cleavage' (Deegan-Krause 2007, 540). The third interpretation puts more emphasis on agency where political elites shape or create the cleavages and party system from above (Przeworski and Sprague 1986; Torcal and Mainwaring 2003). Here cleavages are the competitive divisions on an overarching issue, requiring conflict on values even if this is manufactured by elites and without any structural basis.

We argue that party systems are potentially based on group divisions that are far older and less visible than have hitherto been thought. Our research supports the view that political elites can indeed shape the party system and that party systems are not determined by social factors, but it suggests that the conflicts on which party systems are based are themselves based on values, which are socially structured. By their nature we would expect cleavages to be durable and it might be difficult to create a cleavage without any social basis, even if the social basis is an outgrowth of political activity. Without a social structural basis political entrepreneurs' attempts to create new issues to induce competitive divisions would be more easily successful and ultimately lead to more volatility than we actually observe.

\section{The Anomalous Case of Ireland}

One of the enduring puzzles of Irish politics and, as a result, an enduring puzzle for comparative political scientists, is the Irish party system. Over 30 years ago John Whyte (1974) claimed the party system to be sui generis: unlike the rest of Europe as it was 'without social bases'. Ken Carty $(1983,1)$ was puzzled by the fact that one found parties 'heterogeneous in their bases of support, relatively undifferentiated in terms of policy or programme, and remarkably stable in their support levels'. Although Michael Laver (1986) has found some social bases for partisan support and Tom Garvin (1974) and Mair (1987) have argued for the influence of certain issues in determining political competition, the party system remains 'one of the most intriguing mysteries of Irish politics' (Gallagher and Marsh 2002, 180). Evidence from expert surveys, opinion polls and candidate surveys all fail to identify strong distinctions between the two largest parties, Fianna Fáil and Fine Gael (Benoit and Laver 2003 and 2005; Gilland Lutz 2003).

Ireland then represents an anomaly that existing theories in political science cannot explain. Anomalies are central to our understanding of social phenomena-indeed central to science-in that they are a means by which theories can be quickly disproved (Rogowski 2004; Freedman 2008). Also attempts to incorporate anomalies in established empirical generalities can allow theoretical development. There have been arguments put forward about the Irish party system to fit it into the Rokkan cleavage structure. Of the types of cleavage divisions mentioned, the centre-periphery has been most used by scholars of Irish politics. Garvin (1974) 
argued that the party system was split on these lines where the peripheral west of Ireland represented by Fianna Fáil came to dominate the centre in Dublin. But he and other authors could identify no strong social structural basis for it, and its manifestation in terms of issue or values appeared weak at best. They point to Fine Gael being the party of the large farmer and receiving its support in the east, midlands and urban areas (Manning 1972), and that Fianna Fáil was strongest in the rural west (Garvin 1977), but these relationships are not as strong as is made out (Fianna Fáil's electoral advance was nationwide), and are rarely tested systematically. As Richard Sinnott (1984) and Carty (1983, 94-97) have pointed out, Cumann na nGaedheal (the precursor to Fine Gael) was disproportionately strong in the west of Ireland.

Sinnott (1984) made the point that Ireland was a textbook example of the LipsetRokkan freezing hypothesis in operation. The issue of the relevant mobilising election where enfranchisement was extended to all adult males was nationalism, where the centre was Britain and the periphery was Ireland, and the subsequent party system was then divided on these lines. The decision by Labour to abstain from this election was then seen as crucial in allowing nationalism to become the defining issue of the emerging party system (Farrell 1970). There is also a problem with this argument. If the party system divides on centre-periphery lines, it is not between unionism (with Britain) and (Irish) nationalism, the subject of the division in the 1918 election. Fianna Fáil and Fine Gael divide on the type of nationalism; that was not at issue in 1918. Therefore that election did not feature the conflict that was going to divide Irish politics or form the basis for the party system.

Studies that have attempted to explain the basis for the Treaty split in 1922 have failed to identify any significant variable. So poverty, emigration, land agitation or rural/urban divide are not found to be important (Garvin 1996; Hart 1997 and 2003). They emphasise personal loyalties rather than systemic or cleavage differences (Hart 2003). Although some do look back to types of nationalism, they tend to look no further than 30 years back. Peter Hart (2003) found that exposure to cultural nationalism was alone among the variables that correlated with the distribution of anti-treaty activity. This analysis is problematic in that it does not explain why one became exposed to such activities in the first place. These studies are based on aggregate geographical data and treat political violence as the dependent variable. None look at members of the Dáil (parliament) and how they voted in a systematic way.

Commentators still refer to the civil war politics of the Irish party system, but it is not obvious why the 1922-23 civil war would determine the party system for so long. The main issue of the split was the stipulation in the Anglo-Irish Treaty for an oath of allegiance to the British monarch but this became irrelevant for most after 1927 when Fianna Fáil agreed to swear the oath as an 'empty gesture'. It is clear that the partisan structure of the civil war divisions 'lasted long after the issues that caused the initial division lost their salience' (Kissane 2005, 2). So the party system is based on an issue that turned out not to be terribly important. It would be surprising if the progeny of the civil war were as simple as the proximate issues historians deal with.

We agree with most political scientists that there is a cleavage basis to Irish politics and that the defining cleavage is the centre-periphery. We also agree that type of 
nationalism' divides the two main Irish political parties, that many of the scholars' intuitions are right and that their evidence is valid. But we offer a more complete explanation of the Irish party system, with more rigorous testing of our proposition. First we briefly trace the historical antecedents to the emergence of the Irish party system-the migrations into Ireland from the 12th century and the subsequent varieties of Irish nationalism.

\section{The Gaelic Irish, Old and New English}

What we now think of as a homogeneous Irish people is the result of a number of waves of immigration. Little is known about the immigrants before the Vikings in the 8th to llth centuries, but in what must surely have been one of the earliest nationalist tracts, the 11 th-century An Lebor Gabála (Book of Settlements) created a myth of a common set of ancestors to the Gaelic (native Irish) people. Gaelic Ireland was politically fragmented and its social structure stratified. Gaelic society is thought to have been communal in its nature with societal divisions based on small units of land rather than dominated by a single family unit (Foster 1988, 8-9). Although the Vikings introduced money, enabling commerce and trade, and founded the first secular urban areas, the crucial invasion was not theirs, but the Anglo-Norman invasion in the 12th century (in fact their arrival was as a result of an invitation by a Gaelic chief hoping to use their military strength to defeat a rival). The Anglo-Normans or Old English as they became known then colonised the country and settled primarily around the Viking cities and towns in the east and south.

The descendants of the English (as they called themselves) invaders suffered a decline in the 14th century and there was some mixing of the two cultures, but the groups remained distinct as the Old English 'spoke English ... were firmly attached to English legal procedures; and ... owed unquestioning loyalty to the English Crown' (Canny 1989, 88). As well as speaking a different language, they differed culturally from the Gaelic population in that they celebrated a different form of religion, an ultramontane Catholicism as opposed to the more mystical Christianity with pagan influences of the natives (Clarke 2000, 24). They were wealthier, more settled through clearer ownership of land and remained a distinct group through high rates of endogamy (Foster 1988, 51).

In the 17th century the Protestant English regime came to view the Old English with suspicion and forced them to declare their loyalty either to its regime or to Rome. The ensuing wars in the 1640s caused the Gaelic Irish and Old English to form a political and military alliance against Protestant New English occupation and many historians cease to differentiate between the two groups after this period. But distinctions can be made, and 'long-standing differences of culture, self image and political allegiance did not disappear' (Connolly 1997, 46). Roy Foster (1988, 149) for instance distinguishes between the 'compromising Old English and intransigent Gaelic Irish' at the end of the 17th century. However for historians the distinctions were fading by the start of the 18th century (Connolly 2008, 170) and by the end of that century the (Protestant) Irish nationalist Wolfe Tone attempted to bridge the structural divides by famously appealing to the 'common name of Irishman'. 
Whether the social distinctions were eliminated however is uncertain. Although many of the Old English would have lost their lands through Cromwellian plantations which saw the arrival of the New English, it seems unlikely that the groups that had formed a coalition but were divided by language, class and national identity would be subsumed by a shared Catholicism (especially one that was quite differentiated) or would have ceased to follow their own cultural practices. ${ }^{2}$ It may be that neither Irish nationalist nor English Protestant historians would have had any interest in distinguishing between the two ethnic groups, but rather would prefer to look on a single Irish Catholic class.

The New English that arrived in this era shared an attachment to the English Crown, language and law with the Old English, and a common origin as nonindigenous, non-Gaelic settlers from England, but the New English were Protestant and became associated with what became the Irish unionist political tradition that prioritised the link with Britain. These were wealthy and relatively small in number. Despite their unionism they enjoyed and benefited from the self-rule allowed through the Irish parliament, and especially the freedom to set import duties, which effectively allowed their nascent industries to operate behind protectionist barriers.

\section{Varieties of Nationalism}

It is possible to speculate that these migrations are linked to what Jeffrey Prager (1986) identified as two traditions in Irish nationalism: Irish Enlightenment (constitutionalist) and Irish Irelander (culturally Gaelic and separatist). The Irish Irelander or Gaelic Romantic tradition regarded anything anglicised as necessarily evil and balked at anything it regarded as British, including, bizarrely, commerce and urban living. The Irish Enlightenment tradition admired English liberal democracy and its institutions but wished them to be put to work for the benefit of Irish people (Prager 1986, 44; Kissane 2002, 143). We argue that these traditions were influenced by the cultural legacy of the ethnic groups. So Garvin (1981, ch. 2) notes the Gaelic roots to violent/separatist Irish nationalism and David Fitzpatrick (1998, ch. 1) distinguishes between constitutionalist nationalists and the more radical Gaelic republicans. Especially after the Act of Union some descendants of New English settlers, perhaps forced by indifference or hostile British attitudes, also adopted nationalist politics, usually as constitutionalist and certainly not as cultural nationalists (Smyth 1993). So can these early ethnic groups be linked to the modern Irish party system and how would values have passed from generation to generation?

\section{Transmission of Political Values}

We suggest that the different groups held distinct political values and outlooks that were transmitted through family socialisation. There has been some support recently for a genetic basis for voting (Fowler et al. 2008). This is not implausible as much of human personality is genetically heritable and we can link personality to political ideology (Benjamin et al. 1996; Caprara et al. 2006). However, Luigi Cavalli-Sforza (1993) discounts the possibility that genetic heritage may play a part 
on the basis that the sociological explanation seems to work. We agree, and do not believe a genetic component is necessary-and certainly none that links to specific parties as opposed to ideologies-but rather that the causal mechanism of family socialisation is sufficient. We envisage shared dinner-table discussions rather than shared bloodlines accounting for the passage of these differing political loyalties and values down through the generations.

This mode of transmission is a logical mechanism given the long-standing patriarchal nature of Irish society, where the male head of the household would usually dictate the political and cultural values of the family. As Michael Marsh et al. (2008: 59) have observed, the fact that it makes sense to ask whether a family 'is Fianna Fáil' or 'is Fine Gael' says a lot about the links between politics and family in the country. Surveys both of voters (Marsh et al. 2008) and of political activists (Garvin 1976) have found political loyalties and the instigation of political interest to be rooted in the family. Irish surnames are patrilineal and so are transmitted in a parallel manner to these political and cultural values-hence their utility to us in tracing the differing political outlooks back to their roots.

Transmission by family socialisation also means that common scenarios like false paternity or grandparents from different ethnic backgrounds to the father will not attenuate the link between surnames and political values, as they would if it were driven by genetics. The fidelity of transmission of political outlook will of course itself be attenuated over time; however, even today there is a high coincidence of party loyalty between Irish parents and children, highlighting the strength of family socialisation right into the modern era (Marsh et al. 2008, 72-77).

\section{Data and Method}

Genetic studies are now commonly used to study ancient population movements and to verify and disprove some theories proposed in archaeology and other disciplines. In particular tracing the Y chromosome, passed though the male line, offers a way to date elite-led population movements (Oppenheimer 2006, 4-5). In order to test if the modern Irish party system is based on centuries-old population movements we rely on an analysis of the distribution of surnames. Ireland is an ideal subject for this type of analysis as Irish surnames have maintained a patrilineal heritage from about the 10th century. The country also possesses a wealth of genealogical knowledge and the ethnic origin of most surnames is known, opening up the possibility of using surnames as a proxy for ethnic heritage. Ireland is rare in having extant markers that capture such ancient ethnic differences. Recent genetic analyses of Irish surnames have confirmed the general reliability of this genealogical information. For example, DNA samples taken from hundreds of Irish men show that two men sharing the same Irish surname are many times more likely (over 30 times on average) to share a genetic marker of common patrilineal ancestry than two random Irish men (McEvoy and Bradley 2006). While factors like false paternity have attenuated the (still significant) genetic signal embedded in Irish surnames they will not necessarily have had an effect on any link between surnames and political values (as family socialisation is blind to genetics), though cases of false designation will have attenuated both. Genetic studies like the above 
corroborate the genealogical data and point to a general congruence of surnames with patrilineal ancestry. With the high degree of knowledge on the origin of Irish surnames, this makes them a uniquely useful proxy for ethnic heritage. If our hypothesised relationship of the effects of ethnic heritage is correct we expect that there will be significant biases in the distribution of surnames between the parties, and that Fianna Fáil will have a bias in favour of Gaelic surnames and Fine Gael a bias in favour of Old and New English surnames.

The unit of analysis is individual legislators (TDs) in the Irish Lower House, Dáil Éireann. Each individual is counted only once regardless of number of terms served. We chose TDs as the literature on cleavages points to the importance of elite activity in forming party systems (Torcal and Mainwaring 2003). Using genealogical sources, we coded the origin of the surnames of every TD elected to Dáil Éireann from its foundation in 1919 to the 2007 Irish general election $(n=1,156)$. The data were taken from an Irish electoral database (http://www.electionsireland.org) and these were cross-checked with Michael Gallagher's (1993 and 2009) data. TDs are coded according to the last party they represented. The major surname cohorts in Ireland are the indigenous Gaelic and the Old and New English. Irish surnames predate the ancient population movements we study and have ethnic information embedded in them. In fact, almost all surnames' origins are known (1,144 of 1,156 TDs; 99 per cent). The 636 surnames found in the data set had one or more of the following origins: Gaelic, coded G; Old English (N); New English (E); Scottish (S); Welsh (W); Viking/Norse (V); French (e.g. Huguenot refugees in the 17th-18th centuries) (F); Other (names of known origin, but of small frequency, e.g. Jewish families originally from Eastern Europe) (O); and Unknown (U). Nearly three quarters (857 of 1,156 TDs; 74 per cent) of the members elected to the parliament bear a surname that is exclusively of either Gaelic or Old/New English origin (see coding protocol in Appendix I).

On the basis of our theoretical expectations we examined the political affiliation of the TDs to see if there were any biases between the representatives of the three largest political parties (we include the small Labour party for which we have no theoretical expectations). To validate the method we use in this study we carried out a similar surname-based analysis on local election candidates in Northern Ireland (Byrne and $\mathrm{O}^{\prime}$ Malley (forthcoming)), a neighbouring jurisdiction that has a highly polarised political system whose ethnic roots are well established (Gallagher 1995). If this method failed to find differences here, then any results from the much more difficult case of the Republic of Ireland would be void. We find extremely significant differences in surname origin levels between parties from different traditions, and the biases are as expected given the region's political and population history, and the established links between the two.

\section{Results}

Of Fianna Fáil TDs (MPs) 64 per cent have had surnames of exclusively Gaelic origin (see Figure 1) compared to 57 per cent overall, with Fine Gael's figure being just 51 per cent. Only 12 per cent of Fianna Fáil TDs have had surnames of Old and New English origin, compared to 17 per cent overall and 22 per cent for Fine Gael. 


\section{Figure 1: Observed and Simulated Surname Origin Levels in Irish Political Parties}

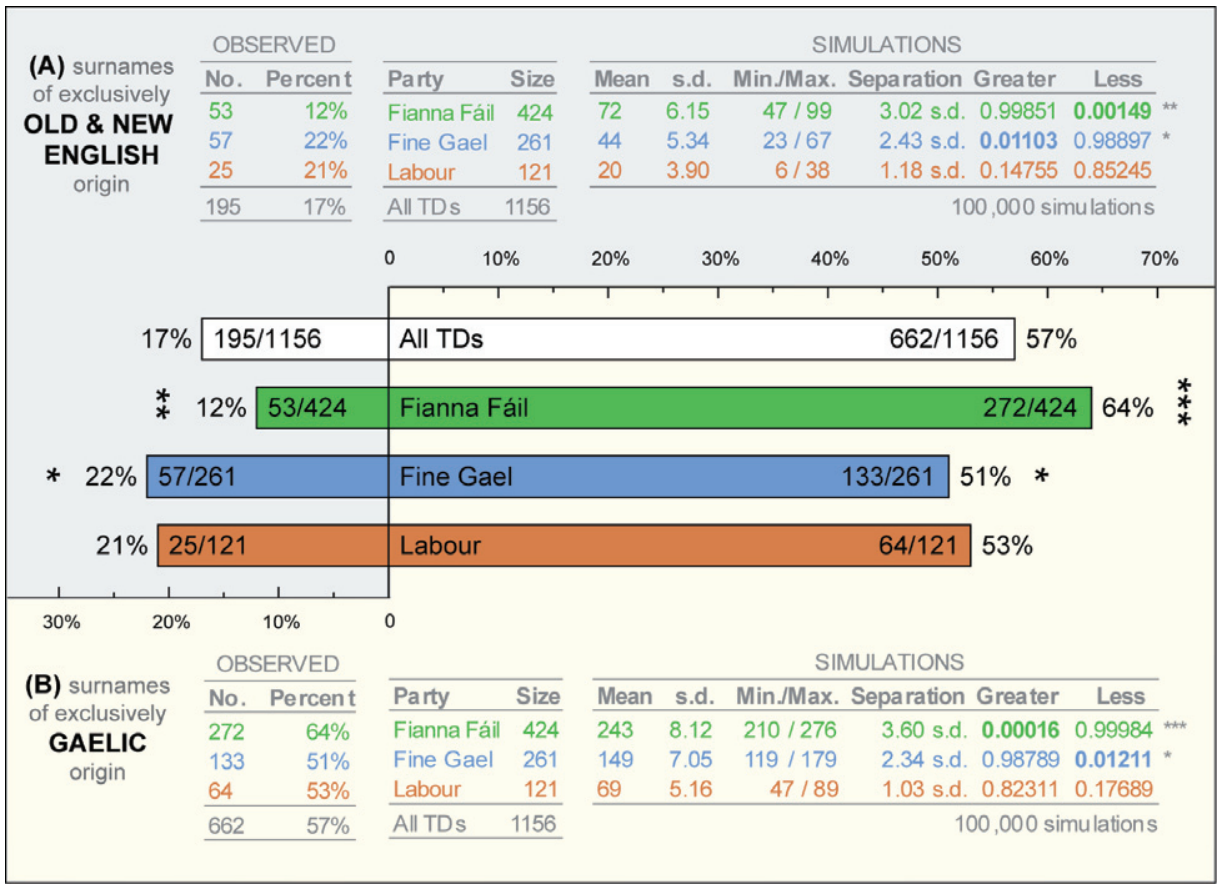

Notes: Percentage of TDs with surnames whose origin is exclusively (A) Old \& New English or (B) Gaelic, for all TDs (white bars), Fianna Fáil (green), Fine Gael (blue) and Labour (red). Exact percentages and counts are displayed outside and inside each bar, respectively. Observed values that are significantly different from that expected by chance (calculated from 100,000 simulations) are marked by asterisks $\left({ }^{*} P<0.05,{ }^{* *} P<0.01,{ }^{* * *} P<0.001\right)$. Details of the mean and standard deviation (sd) of the simulations are given for each party in both panels. 'Min./Max.' columns report the smallest and largest counts seen in simulations and 'Separation' is the number of sd the observed value is from the mean. 'Greater' and 'Less' denote the proportion of simulations where a party has more or fewer surnames of a given type than in the observed data. This gives an empirical measure of the significance of the observed level. ${ }^{*} P<0.05,{ }^{* *} P<0.01,{ }^{* * *} P<0.001$

Randomly distributing the TDs across parties 100,000 times (see Appendix IIMethods) and counting the proportion of simulated parties in which the number of TDs with a surname with a particular ethnic origin exceeds or is less than the observed number of such TDs in the real data gives an empirical measure of the statistical significance of the observation, under the null hypothesis of a random distribution of TDs (Figure 1). In the real data, 57 per cent of all TDs ever elected have had surnames of exclusively Gaelic origin and 17 per cent of exclusively old and New English origin. We find that Fianna Fáil has significantly more TDs of Gaelic origin and significantly fewer of Old and New English origin than would be expected by chance $(P=0.00016$ and $P=0.0015$, respectively). Conversely, Fine Gael has significantly fewer TDs of Gaelic origin and significantly more of Old and New English origin than one would have expected by chance $(P=0.012$ and 
$P=0.011$, respectively). The directions of these biases show the two largest Irish political parties to be significantly polarised. This polarisation is illustrated in Figure 1 in the rightward shift of green Fianna Fáil bars and the leftward displacement of the blue Fine Gael bars.

To confirm both parties' differences from population we also compared the surname origin levels in each to those seen in the random set of citizens in a national household survey. ${ }^{3}$ We found Fianna Fáil TDs had significantly more Gaelic surnames than seen in the population at large $(P=0.0018$; chi-squared test $)$ and Fine Gael TDs had significantly more Old and New English surnames than expected given the population $(P=0.0013$; chi-squared test), the same biases we see within our parliamentarian data set.

Not only are Fianna Fáil and Fine Gael different to population, these parties are, as expected, significantly different to each other (see Figure 2). For Gaelic surnames this difference in levels is highly significant $(P=0.0009$; chi-squared test; Figure 2a), indicating a bias in affiliation toward Fianna Fáil for those with Gaelic ancestry. The proportion of TDs with Gaelic surnames representing the third biggest party in Ireland, the Labour party (53 per cent), is closer to Fine Gael (51 per cent), with the difference in levels between Labour and Fianna Fáil (64 per cent) being larger, and significant $(P=0.03)$. In the case of TDs with surnames of exclusively Old and New English origin (Figure $2 \mathrm{~b}$ ) the reverse pattern is found with a bias in affiliation toward Fine Gael, 22 per cent of whose TDs have had surnames of this origin, as compared to only 12 per cent of Fianna Fáil, a highly significant difference $(P=0.002)$. As with Gaelic surnames the level for Labour is intermediate $(21$ per cent) between the two larger parties, but closer to and not significantly different from the level for Fine Gael, and more different from Fianna Fáil, with marginal

\section{Figure 2: Biases in Surname Origin between Parliamentarians of the Three Main Irish Political Parties}
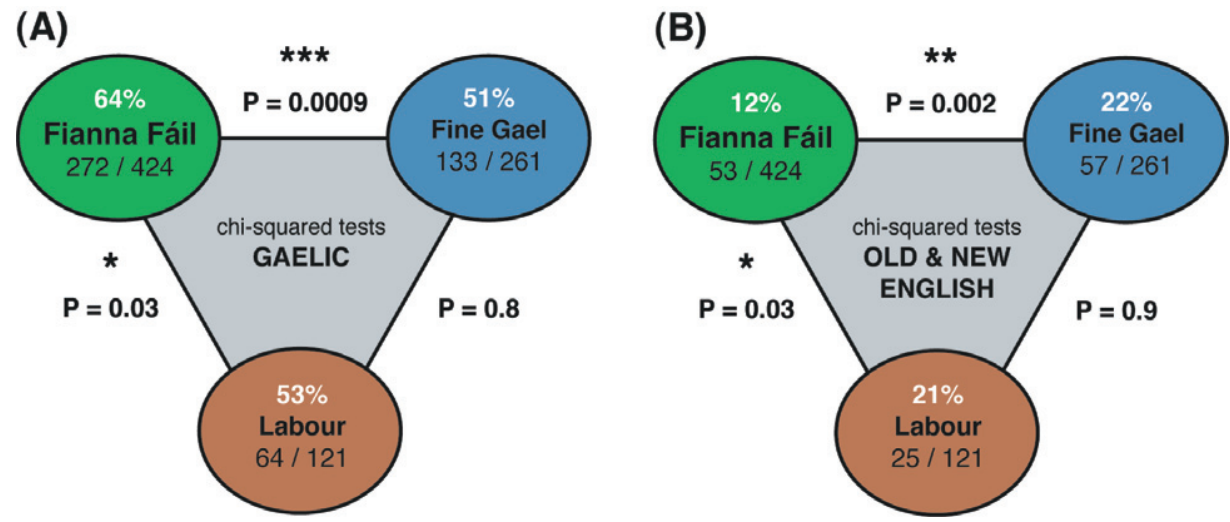

Notes: Surname origin levels in the three main Irish political parties and the significance of pair-wise chi-squared tests between them for surnames whose origin is either exclusively (A) Gaelic and (B) Old \& New English 
significance $(P=0.03)$. These comparisons reveal a significant difference in the ethnic background of representatives of the two main parties.

\section{Persistence over Time}

We calculated surname origin levels for the two main parties and the whole parliament at each election from 1932 to 2007 (see Appendix II-Methods). The biases are remarkably consistent over the 75-year period (Figure 3). Fianna Fáil always has a higher proportion of TDs with Gaelic surnames than either Fine Gael or the parliament at large, while Fine Gael generally has fewer than the whole chamber. The situation is inverted for Old and New English names, with Fianna Fáil always having a lower proportion than either Fine Gael or the parliament, while Fine Gael in turn generally has a lower proportion to the entire parliament. Examining these surname origin levels over the full 75 years shows that these consistent differences are also highly significant $(P<0.00001$ for paired $t$-tests on all six comparisons mentioned above).

Although the biases are consistent over time, some variation is also apparent. The levels for the full parliament are on the whole very consistent, with the only major

Figure 3: Variation of Surname Origin Biases over Time (1932-2007)

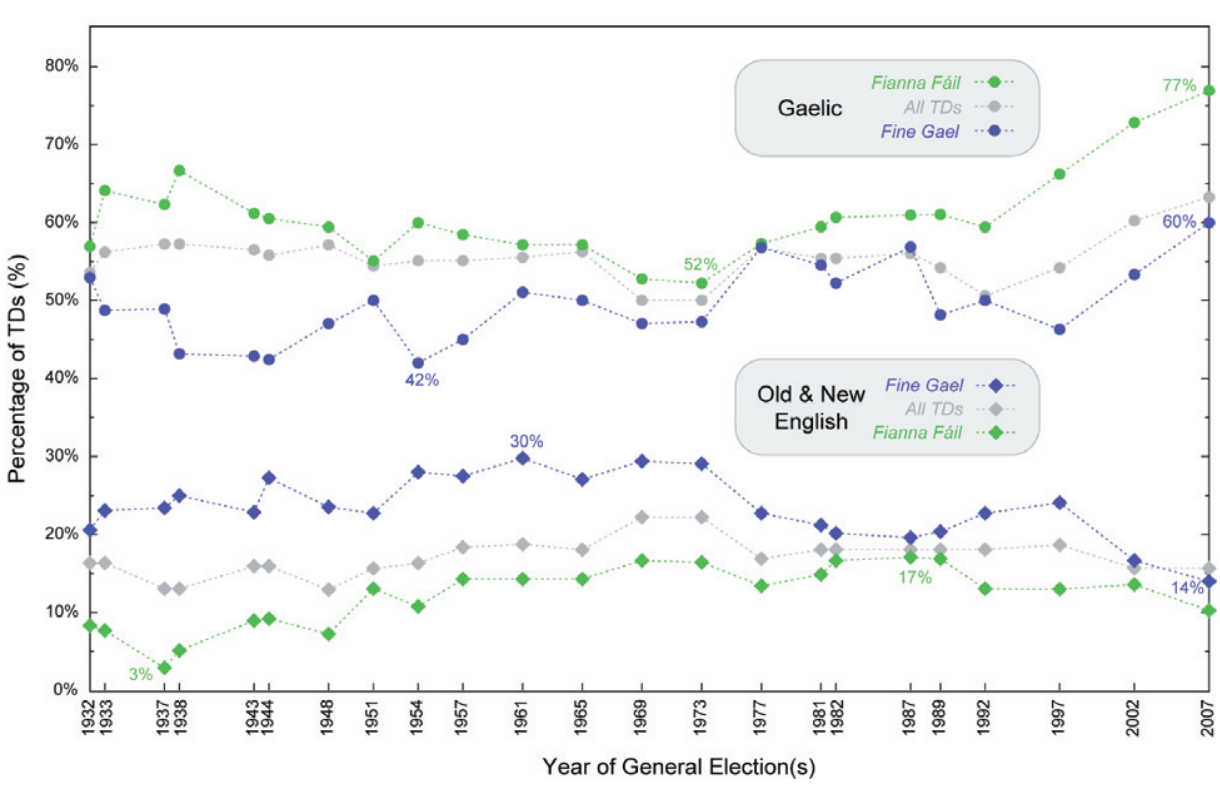

Notes: Percentage of TDs (y-axis) with surnames whose origin is exclusively Gaelic (circles) or exclusively Old \& New English (diamonds), for all TDs (grey), Fianna Fáil (green) and Fine Gael (blue), at Irish general elections from 1932 to 2007 (election dates marked on x-axis). The highest and lowest percentages of Gaelic and Old \& New English names are printed for both Fianna Fáil and Fine Gael. Paired $t$-tests confirm that consistently over this time period the level of Gaelic surnames in Fianna Fáil is significantly higher than that in both the whole parliament and in Fine Gael, while the level in Fine Gael is in turn significantly lower than that in the parliament at large. The converse is true for Old and New English surnames $(P<0.00001$ for all comparisons) 
variation being a rise in the proportion of TDs with Gaelic surnames in the last few elections (Figure 3), perhaps due to the consequences of the introduction of free second-level education in Ireland in the 1960s-a measure that may have disproportionately benefited those of indigenous Gaelic stock who on average would have been likely to have had poorer educational and therefore political opportunities than other citizens. Both parties reflect this recent peak in the proportion of TDs with Gaelic surnames. As we might expect the analysis shows that the extent of the differences has weakened somewhat over time. Nevertheless their role as the bases of Irish party politics over the last three quarters of a century is apparent and strong. Given the antiquity of these origins and the lack of conscious affiliation in the modern era, this is a remarkable continuing impact of centuries-old population movements.

\section{Comparison to Irish Parliamentary Party}

While it is clear that the differences between Fianna Fáil and Fine Gael have persisted through the 20th century we also wanted to see if they could be linked to political groups that predate these parties' formation. In order to do this, and offer further support to our hypothesis that the modern party political divide has roots that predate the Civil War, we looked at the Irish Parliamentary party (IPP), which was the dominant Irish electoral force for 40 years from its foundation in 1882 to the earthquake election of 1918 that effectively wiped it out. It was the standardbearer of the constitutional nationalist tradition in this era, while a more violent radical nationalism also existed at the same time outside parliamentary politics. Over its history the IPP had 206 MPs that represented it in the British House of Commons for constituencies that are now in the Republic of Ireland.

We coded the surnames of these MPs as we did for the TDs (see coding protocol in Appendix I) in order to compare this 19th-century party's surname origin distribution to that of Fianna Fáil and Fine Gael in the 20th century. We found that 52 per cent of its MPs had surnames of exclusively Gaelic origin and 21 per cent had names of exclusively Old and New English origin. These levels are essentially identical to those for Fine Gael (51 per cent Gaelic; 22 per cent Old and New English) but are significantly different to those for Fianna Fáil (64 per cent Gaelic; 12 per cent Old and New English; $P=0.006$ for both comparisons).

These results support the hypothesis that there was a migration of support from the IPP to Fine Gael after 1918. They also confirm the more Anglo-Norman character of the constitutional nationalist tradition in the 19th century. Fianna Fáil may have mobilised voters in the 20th century who were either not engaged in electoral politics previously (but may have had involvement in the extra-parliamentary nationalism that existed alongside the IPP) and/or were not enfranchised in earlier eras (due to property restrictions on the vote) and who appear to have been more heavily of Gaelic origin.

\section{Discussion: The Ethnic Bases for Irish Politics}

The fact that we find significant differences in the surnames of legislators strongly supports our hypothesis that the party system is based on ethnic roots, and that 
there are social bases for the Irish party system, though these are hidden. What we detect in the modern political arena is the legacy of divisions between ancient self-identifying ethnic groups. Their movements many centuries ago have a previously unappreciated systemic impact on the modern party system. These findings support much of the literature on the Irish party system but give a fuller understanding of its deep and hidden roots.

We noted above that the two parties that emerged are programmatically similar and that their social bases for support are heterogeneous. It is reasonable to ask what the differences between the two parties are, and how both had thrived for so long; the differences are certainly not clear. At a Fine Gael parliamentary party meeting in the mid-1960s a member claimed not to know the difference between it and Fianna Fáil and others agreed (Manning 1999, 341). A survey of Fine Gael members shows that they tend to emphasise its honesty and integrity compared to Fianna Fáil, but failed to identify programmatic differences (Gallagher and Marsh 2002, 180-190).

Although the two parties are both socially and economically conservative the differences are consistent with our hypothesised ethnic roots. Immediately after formation Fianna Fáil portrayed itself as the party of 'men of no property'. This resonated partly because it had an element of truth to it. That Fine Gael was seen as a party of notables, dominated by the professionally qualified, moneyed and socially sophisticated who attended middle-class religious schools (Mair 1987, 122) is what one would expect of the descendants of the Old and New English. We expect that the descendants of the Gaelic Irish should be more radical in their nationalism, while the Old and New English would have a greater attachment to Britain and British institutions. Fine Gael was seen by many as the party of the British Commonwealth, and it has advocated the removal of the compulsory teaching of Irish in schools. Fianna Fáil was for a time an 'extra-parliamentary' party, refusing to recognise the British-imposed institutions it came to dominate, regarding itself as only 'a slightly constitutional party'. Within the new state's self-image as a Gaelic country, in which other groups were ignored, Fianna Fáil rejected that it was merely a political party, but still sees itself as a 'national movement'.

Many saw the major division between Fianna Fáil and Fine Gael as their differing nationalism. For Garret FitzGerald (1991, 492-493), former Fine Gael leader and Taoiseach (prime minister), in considering the historical differences between the parties he felt 'the role of Fine Gael [is] to pose an alternative, pluralist concept of Irishness that would have room for unionist as well as nationalists'. Fianna Fáil politicians have been much more likely to revert to anti-British rhetoric than those from Fine Gael. Although nationalism does not feature greatly in election campaigns, 'territorial nationalism can be seen as primarily a domain of identification cementing long-term partisan loyalties on one side or the other of the Fianna Fáil-Fine Gael divide' (Mair 1987, 145). In an analysis of voters' attitudes and opinions about party policy positions, Marsh et al. $(2008,50)$ find that issue to be the only one on which Fianna Fáil and Fine Gael can be distinguished. The two parties had differing responses to the episodic violence from the Irish Republican Army (IRA) with Fine Gael tending to put much more emphasis on law and order and the defence of the state. Another area of continuing controversy is Irish 
neutrality, which Fine Gael is explicitly open to dropping (Devine 2009). The parties' attitudes to Europe also show differences with Fine Gael being more avowedly pro-European than the more nationalist Fianna Fáil (cf. Hayward and Fallon 2009; Reidy 2009). These are policy differences we might expect of an elite-led party formed by descendants of the Old and New English.

This research on Ireland demonstrates that the social divisions that party systems can be based on may be much older than those suggested by Lipset and Rokkan, and that they can be influential in the formation of party systems even where the social divisions themselves are no longer extant. Furthermore, Fianna Fáil succeeded in mobilising a section of the population around an issue not regarded as important by many outside the political and military elite. This indicates that social cleavages can be 'constructed' by political elites, but Fianna Fáil did not do this out of nothing. It was based on an underlying difference in values regarding type of nationalism, which was itself based on older ethnic differences. Nor are these underlying cleavages immune from change. In 2011 it suffered a severe loss in support which can be most easily explained by theories of economic voting. The collapse in Fianna Fáil's support and rejuvenation of Fine Gael in the 2011 earthquake election shows that cleavages are not deterministic but interact with the decisions of political agents. In that, at least, Ireland was unexceptional.

\section{Appendix I: Coding Protocol}

We used Grenham's Irish Surname (Grenham 2003) database as the source for the coding. This was recommended to us by professional genealogists. Where Grenham had no information we used MacLysaght's (1985) book on surname origins. The surnames were independently coded twice and a small number of discrepancies were reconciled by more detailed examination of the genealogical sources. Where surnames had multiple potential origins, names were given multiple codes. So, for instance, TDs with the quite common surname, Lynch, which has two potential origins (Anglo-Norman and Gaelic) were coded (N, G).

At times surnames have been changed for political purposes. As different groups assume power, people adapt their surname to suit the new regime. So in the 1920s it was common for people to Gaelicise their surname; for instance Charles Burgess, an Irish nationalist of English origins, changed his name to Cathal Brugha. Gaelicised and anglicised versions of surnames were coded to represent their original synonym; so Brugha is coded E. By taking the root name we ensure we are not misled by the adaptation of surnames for political/economic purposes.

Only surnames that had exclusively Gaelic origins (G) or Old and/or New English origins (coded E, N, NE or EN) were used in the analyses presented here. For double-barrelled names we coded both and where both were in agreement we kept the TD in the analysis; otherwise it was dropped from the analysis.

\section{Appendix II: Methods}

Perl (http://www.perl.org) scripts were written to automate randomisations, counting and statistical operations on the data. The R package (http://www.r-project.org) 
was used to carry out statistical analysis. Chi-squared tests were used to compare surname origin levels between parties. T-tests were used to compare surname origin levels between the parties over time.

\section{Randomisations}

We carried out 100,000 randomisations of surname-party assignments. For each simulation we held the size of each party fixed as in the real data but randomly distributed TDs across the parties. This resulted in parties of the same size as in the real data but with a random sampling of the TDs. We then counted the number of Gaelic and Old and New English surnames in each randomised party. We calculated the means and standard deviations of the number of Gaelic surnames and Old and New English surnames in the parties (presented in the tables in Figure 1). These means represent the number of TDs with a given surname type expected by chance in a party of that size. We also counted the number of randomisations that had more or less Gaelic and Old and New English surnames than observed in the real data ('Greater' and 'Less' columns in the tables in Figure 1), giving a direct measure of whether the level of a surname type seen in the real data is significantly more or less than expected by chance.

\section{Timeline Analysis}

For each general election from 1932 (the first in which both major parties examined in this study were represented) to 2007 the proportion of TDs elected with surnames of exclusively Gaelic origin or exclusively Old and New English origin were calculated for the whole parliament and for both Fianna Fáil and Fine Gael (data displayed in Figure 3). In 1982 there were two general elections and in this case the results from both were amalgamated and proportions calculated on the combined data. Paired $t$-tests were used to compare the proportions of each surname type between the two parties and between each and the parliament over the entire 75-year period.

\section{About the Authors}

Kevin P. Byrne, Smurfit Institute of Genetics, Trinity College Dublin, Dublin 2, Ireland, email: kevin.byrne@tcd.ie

Eoin O'Malley, School of Law and Government, Dublin City University, Dublin 9, Ireland, email: eoin.omalley@dcu.ie

\section{Notes}

We would like to thank Dan Bradley for his encouragement and support of this study. We are grateful to Michael Gallagher, John Garry and Alex Baturo for their advice and their comments on an earlier version of this article. We thank Seán Donnelly of www.electionsireland.org for providing the historic election data used in this research and gratefully acknowledge the research assistance provided by Sive Finlay and Emma Finlay.

1. We use the term ethnic to denote a group identity based on descent and genetic, cultural and historical inheritance, where the members share a culture and interests that are sub-national in nature but where the members are not closely related (Chandra 2006). While we argue that the Gaelic, Old and New English groups constituted ethnic groups in the past we do not assert that they 
still exist in the highly homogeneous modern Irish population. Although these ethnic groups no longer exist, we show that their political legacy does.

2. The distinction between the three types of Irish is necessarily stylised. Inevitably there was some mixing as Gaelic elites in the east became anglicised and English elites in the west became Gaelicised. We also see some of the Old English effectively entering New English Protestant society.

3. Irish National Election Study (2002), with 2,663 respondents, carried out by the Economic and Social Research Institute (ESRI) of Ireland.

\section{Bibliography}

Bartolini, S. and Mair, P. (1990) Identity, Competition and Electoral Availability: The Stabilisation of European Electorates, 1885-1985 (Cambridge: Cambridge University Press).

Benjamin, J., Li, L., Patterson, C., Greenberg, B. D., Murphy, D. L. and Hamer, D. H. (1996) 'Population and familial association between the D4 dopamine receptor gene and measures of novelty seeking', Nature Genetics, 12:1, 81-84.

Benoit, K. and Laver, M. (2003) 'Estimating Irish party policy positions using computer wordscoring: The 2002 election-a research note', Irish Political Studies, 18, 97-107.

Benoit, K. and Laver, M. (2005) 'Mapping the Irish policy space: Voter and party spaces in preferential elections', Economic and Social Review, 36, 83-108.

Byrne, K. and O'Malley, E. (forthcoming) 'What's in a name? Using surnames as data for party research', Party Politics.

Canny, N. P. (1989) 'Early modern Ireland c. 1500-1700', in R. F. Foster (ed.), The Oxford History of Ireland (Oxford: Oxford University Press), 88-133.

Caprara, G. V., Schwartz, S., Capanna, C., Vecchione, M. and Barbaranelli, C. (2006) 'Personality and politics: Values, traits, and political choice', Political Psychology, 27:1, 1-28.

Carty, R. K. (1983) Electoral Politics in Ireland: Party and Parish Pump (Dingle: Brandon).

Cavalli-Sforza, L. L. (1993) 'How are values transmitted?', in M. Hechter, L. Nadel and R. E. Michod (eds), The Origin of Values (New York: Aldine de Gruyter), 305-318.

Chandra, K. (2006) 'What is ethnic identity and does it matter?', Annual Review of Political Science, 9 , 397-424.

Clarke, A. (2000) The Old English in Ireland, 1625-42 (Dublin: Four Courts Press).

Connolly, S. J. (1997) 'Culture, identity and tradition: Changing identities of Irishness', in B. Graham (ed.), In Search of Ireland (London: Routledge), 43-63.

Connolly, S. J. (2008) Divided Kingdom: Ireland 1630-1800 (Oxford: Oxford University Press).

Deegan-Krause, K. (2007) 'New dimensions of political cleavage', in R. J. Dalton and H.-D. Klingemann (eds), Oxford Handbook of Political Behavior (New York: Oxford University Press), 538-555.

Devine, K. M. (2009) 'Irish political parties positions on the European Union Common Foreign and Security Policy/European Security and Defence Policy and Irish neutrality', Irish Political Studies, 24:4, 467-490.

Farrell, B. (1970) 'Labour and the Irish political party system: A suggested approach to analysis', Economic and Social Review, 1:4, 477-502.

FitzPatrick, D. (1998) The Two Irelands, 1912-1939 (Oxford: Oxford University Press).

FitzGerald, G. (1991) All in a Life: An autobiography (Dublin: Gill \& Macmillan).

Foster, R. F. (1988) Modern Ireland 1600-1972 (London: Penguin).

Fowler, J. H., Baker, L. A. and Dawes, C. T. (2008) 'Genetic variations in political behavior', American Political Science Review, 102, 233-248.

Freedman, D. A. (2008) 'On types of scientific enquiry: Nine success stories in medical research', in J. M. Box-Steffensmeier, H. E. Brady and D. Collier (eds), The Oxford Handbook of Political Methodology (Oxford: Oxford University Press), 300-318.

Gallagher, M. (1995) 'How many nations are there in Ireland?', Ethnic and Racial Studies, 18:7, 715-739.

Gallagher, M. and Marsh, M. (2002) Days of Blue Loyalty: The Politics of Membership of the Fine Gael Party (Dublin: PSAI Press).

Gallagher, M. (ed.) (1993) Irish Elections 1922-44: Results and Analysis (Limerick: PSAI Press). 
Gallagher, M. (ed.) (2009) Irish Elections 1948-77: Results and Analysis (London: Routledge).

Garvin, T. (1974) 'Political cleavages, party politics and urbanisation in Ireland: The case of the peripherydominated centre', European Journal of Political Research, 2:3, 307-327.

Garvin, T. (1976) 'Local party activists in Dublin: Socialization, recruitment and incentives', British Journal of Political Science, 6:2, 269-280.

Garvin, T. (1977) 'Nationalist elites, Irish voters and political development: A comparative perspective', Economic and Social Review, 8:2, 161-186.

Garvin, T. (1981) The Evolution of Irish Nationalist Politics (Dublin: Gill and Macmillan).

Garvin, T. (1996) 1922: The Birth of Irish Democracy (Dublin: Gill \& Macmillan).

Gilland Lutz, K. (2003) 'Irish party competition in the new millennium: Change, or plus ca change?', Irish Political Studies, 18, 40-59.

Grenham, J. (2003) 'Grenham's Irish surnames', Eneclann, Dublin, CD-Rom database.

Hart, P. (1997) 'The geography of revolution in Ireland, 1917-1923', Past and Present, 155, 142-177.

Hart, P. (2003) The IRA at War, 1916-23 (Oxford: Oxford University Press).

Hayward, K. and Fallon, J. (2009) 'Fianna Fáil: Tenacious localism, tenuous Europeanism', Irish Political Studies, 24:4, 491-510.

Heath, A. (1981) Social Mobility (London: Fontana).

Kissane, B. (2002) Explaining Irish Democracy (Dublin: University College Dublin Press).

Kissane, B. (2005) The Politics of the Irish Civil War (Oxford: Oxford University Press).

Kriesi, H. (1998) 'The transformation of cleavage politics: The 1997 Stein Rokkan lecture', European Journal of Political Science, 33:2, 165-185.

Laver, M. (1986) 'Party choice and social structure in Ireland', Irish Political Studies, 1, 45-55.

Lipset, S. M. and Rokkan, S. (1967) 'Cleavage structure, party systems and voter alignments: An introduction', in S. M. Lipset and S. Rokkan (eds), Party Systems and Voter Alignments: Cross-National Perspectives (New York: Free Press), 1-64.

MacLysaght, E. (1985) The Surnames of Ireland (6th edn) (Dublin: Irish Academic Press).

Mair, P. (1987) The Changing Irish Party System (London: Pinter).

Manning, M. (1972) Irish Political Parties: An Introduction (Dublin: Gill \& Macmillan).

Manning, M. (1999) James Dillon: A Biography (Dublin: Wolfhound Press).

Marsh, M., Sinnott, R., Garry, J. and Kennedy, F. (2008) The Irish Voter: The Nature of Electoral Competition in the Republic of Ireland (Manchester: Manchester University Press).

McEvoy, B. and Bradley, D. G. (2006) 'Y-chromosomes and the extent of patrilineal ancestry in Irish surnames', Human Genetics, 119:1-2, 212-219.

Oppenheimer, S. (2006) The Origins of the British: A Genetic Detective Story (London: Constable and Robinson).

Prager, J. (1986) Building Democracy in Ireland: Political Order and Cultural Integration in a Newly Independent Nation (New York: Cambridge University Press).

Przeworski, A. and Sprague, J. D. (1986) Paper Stones: A History of Electoral Socialism (Chicago IL: University of Chicago Press).

Reidy, T. (2009) 'Blissful union? Fine Gael and the European Union', Irish Political Studies, 24, 511-526.

Rogowski, R. (2004) 'How inference in the social (but not the physical) sciences neglects theoretical anomaly', in H. E. Brady and D. Collier (eds), Rethinking Social Inquiry: Diverse Tools, Shared Standards (Lanham MD: Rowman \& Littlefield), 75-84.

Sinnott, R. (1984) 'Interpretations of the Irish party system', European Journal of Political Research, 12, 217-241.

Smyth, W. J. (1993) 'The making of Ireland: Agendas and perspectives in cultural geography', in B. J. Graham and L. J. Proudfoot (eds), An Historical Geography of Ireland (London: Academic Press), 399-438.

Tilly, C. (2006) 'Why and how history matters', in R. E. Goodin and C. Tilly (eds), The Oxford Handbook of Contextual Political Analysis (New York: Oxford University Press), 417-437.

Torcal, M. and Mainwaring, S. (2003) 'The political recrafting of social bases of party competition: Chile, 1973-95', British Journal of Political Science, 33:1, 55-84.

Whyte, J. (1974) 'Ireland: Politics without social bases', in R. Rose (ed.), Electoral Behavior: A Comparative (New York: Handbook. The Free Press), 619-651. 